\title{
THE EFFECT OF DIRECT INSTRUCTION MODEL IN PHYSICAL EDUCATION TOWARDS STUDENTS' ADVERSITY QUOTIENT (AQ)
}

\author{
Rola Angga Lardika*1, Singha Tulyakul ${ }^{2}$ \\ Universitas Riau, Indonesia ${ }^{* 1}$, Thaksin University, Thailand ${ }^{2}$ \\ Email: rolaanggalardika@lecturer.unri.ac.id ${ }^{* 1}$, singha2125@ hotmail.com $^{2}$
}

Received: 09 January 2020; Accepted 15 April 2020; Published 3 June 2020

Ed 2020; 5(1): 1-12

\begin{abstract}
The effect of direct instruction model in physical education towards students' adversity quotient (AQ). The purpose of this study is to determine the significance of the effect of direct instruction in physical education and problem-solving skills to survive the problems that faced students (Adversity Quotient). The applied method is experiment one group pretest posttest design. The procedures of this research are observation, interview, treatment program preparation, analysis and conclusion. The research findings are achieved experiment group with direct instruction model giving significant influence towards students' adversity quotient level with score on (sig.),000 $<\alpha=0,005$. Based on the data, it can be concluded that the direct instructional model giving significant affect towards the level of students' adversity quotient.
\end{abstract}

Keywords: Physical Education; Learning Model; Direct Instruction; Adversity Quotient (AQ)

Copyright $\odot$ 2020, Journal Sport Area

DOI: https://doi.org/10.25299/sportarea.2020.vol5(1).4460

How To Cite: Lardika, R. A., \& Tulyakul, S. (2020). The Effect of Direct Instruction Model in Physical Education Towards Students' Adversity Quotient (AQ). Journal Sport Area, 5(1), 1-12.

\section{INTRODUCTION}

Physical Education is an important aspect in building a nation character. Through physical acticity, a person will be abe to keep a movement activity, beside that physical education also impacts indirectly to students' physical development and mental because those are a near relationship with true life. (Abduljabar, 2011). Altough nowadays we often listen that physical education should not be given to students because it can trouble study for other subjects and obviously this case is a wrong perception and thinking. This thing should get a serious attention soon from sport people.

Physical education is not only an activity of physic development in isolation, however it should be in a contex of education generally (Abduljabar, 2010). Obviously the process is done consciously and involves systematic interaction between the doers in reaching the goal that has been determined. As like that has expressed by Metzler (2000) physical education is a part of general education program that contributes through movement experience towards children's growth and development. Physical education is meant as a clear movement education and it should be conducted in appropriate way with the true sense.

Physical education is a part of education program that gives influence from process of learning movement towards the improvement of cognitive, affective and social ability (Abduljabar, 2011). Physical education is defined as education through movement and it should be done in useful way (Amri \& Ahmadi, 2010). Opinions above want a more process in emphasizing on experience through movement so that kids have illustration 
towards every movement that they will do for the future time that agreed with kids' growth level. It is no doubt that few teachers can run rules that desired by opinions above (Mwivanda \& Kingi, 2019).

Physical education is a person education process as individual or society that conducted consciously and systematically through several physical activities for gaining a harmony growth of physical, health, physical fitness, skill, quotient and personality in forming qualified Indonesia generation (Edgen \& Kauchak, 2012). Explicitly, term of physical education needs to be differed with sports. Extensively, sports can be meant as all activities or efforts to push, to awaken, to develop, and to advise both physical strength and spiritual on every human. According to Okorji and Epetuku (2019), sports basically increases coordination of physic, strength, velocity, durability and flexibility.

This believes that physical education that integrated into learning model hopefully it can enhance aspect of students' physchomotoric, cognitive, and affective. Gall, Gall, and Borg (2013) explains the use of accurate strategy or approach will enable various goals of learning process easier to be reached. Learning model of physical education that conducted in schools especially Indonesia, it directs on the use of direct instruction because it is looked that teacher becomes learning center totality. Characteristic from direct instruction is teacher be determination center and teacher directly gives example of learning unite (Metzler, 2000). The lack of variety causes students acting not appropriate with what desired and inclined ignore physical education. Physical education is strategic way to develop students' adversity quotient (AQ) (Stoltz, 2010). Unfortunately, not all teachers of physical education understand thi case so that this aspect inclined is forgotten. Physical education instead builds students sports than establishes students' education (Abduljabar, 2010). That case is estimated happening because the teacher candidates of physical education are supplied forcefully on sport ability than supplied education and teaching skill through approach of the number of teaching didactic and method by students' learning developing. The symptom of the low of student's ability in solving problems in physical education caused the planning of movement learning assignement does not stir up the developing of students' cognitive, affective, emotional, and social (Khairani \& Abdullah, 2018). The planning of movement learning assignment does not enough include movement problem elements that students should solve. The learning of movement that created nowadays inclined forms repetition of movement form and movement exercise than builds students' learning, teacher of physical education is repressed in teaching of basic techniques of sport branching (Abduljabar, 2010). Here is the result comparison of two surveys scales national towards teachers, firstly it was done in 1940 and secondly in 1990, it shows that many changes that had been occurred (Stoltz, 2010).

Table 1. Comparison of Survey Result towards Teachers in 1940 and 1990 (Stoltz, 2010)

\begin{tabular}{|c|c|}
\hline $\begin{array}{l}\text { Main problem that reported by teachers } \\
\text { in } 1940(\text { Stoltz, 2010) }\end{array}$ & $\begin{array}{l}\text { Main problem that reported by teachers in } \\
\qquad 1990 \text { (Stoltz, 2010) }\end{array}$ \\
\hline $\begin{array}{l}\text { - } \text { Snatch to speak } \\
\text { - } \text { Make trouble } \\
\text { - } \text { Run in school paths } \\
\text { - Infringe dressing rules } \\
\text { - } \text { Negligent } \\
\text { - } \text { Chew buble gum }\end{array}$ & $\begin{array}{l}\text { - } \text { Misuse drugs } \\
\text { - } \text { Pregnance alchohol } \\
\text { - } \text { Suicide } \\
\text { - } \text { Assailant } \\
\text { - } \text { Agobery } \\
\end{array}$ \\
\hline
\end{tabular}


Based on Pantauan Pelanggaran Hak Anak (Monitoring of Violation of Child Kids) in Indonesia in 2007-2009, child who faces with law always increases, that is in 2005 numbering 2.341, in 2008 numbering 621 and in 2009 increasing 1.258. This is estimated to increase more, if there is no exact solution it will danger national education (Bingquan, Weisheng, Xudong, \& Wenxiu, 2019). Author estimates the high level of kids who face with law effected they can not face problems that come them so that kids inclined use drugs such as alchohol, narcotic, as one of way to calm self and as an escape from their problems. School as the best place is hoped to be able training and educating students to be readier in accomplishing problems with wise ways and to face the heavier era challenge (Gall, Gall, \&Borg, 2013).

Adversity Quotient (AQ) is an expression in solving problems and ability to stay in problem as like explained above. Adversity quotient is person's ability to stay towards a problem and how far the individual can solve the problem that he/she faces (Stoltz, 2010). Connecting with direct instruction model above, it is needed the good thingking and acting way to produce individu that appropriate with era development (Yakoh, Congrukasa \& Prinyapol, 2015). One research that conducted by Stoltz (2010) adversity quotient proved that it is accurate way for an athlete ability in responding difficulties. From several explanation above, for assisting to enhance students' adversity quotient (AQ), it is required physical education in school that applicated into one learning model that is through direct instruction so that it is expected problems above can be solved for the life quality progress of Indonesia nation generation. It is based on by several opinions above, it needs to make research furthermore towards the influence of physical education that actualized through learning model of direct instruction towards students' adversity quotient (AQ) level.

\section{METHOD}

In this research, author wants to uncover the influence from the particular variable towards another variable. So, the exactest way that author estimates is experiment method. Maksum (2012) stated that experiment research is a research that conducted strictly to know the correlation of cause-effect among variables. Furthermore, one of main character of experiment research is there is a treatment that given to research subject or object. Definition of experiment as like uttered by Rusman (2012) is self experiment from modification that intended and put forward from a condition for determining an occurrence and an interpretation from a change. This research population is all of students in ten grade at SMA Negeri 1 Teluk Kuantan Kabupaten Kuantan Singingi that numbers \pm 250 students. Author will use partly only to represent the population. Although there is sample, it will be also influenced by the limitation of time, energy and cost that owned by the researcher. Technique that researcher uses in determining sample, that is purposive sampling. The number of sample is 33 students. According to Fraenkel and Wallen in Maksum (2012) there is no a certain measure how the number of representative sample. Although they recommend the number of direction as following: 
Tabel 2. Number of Sample Minimal for Based on Kind of Research (Maksum, 2012)

\begin{tabular}{|c|c|}
\hline Kind of Research & Minimal of Sampel Number \\
\hline • Description/Survey & - 100 subjects \\
\hline - Correlational & - 50 subjects \\
\hline - Experiment/Comparative Causal & $\begin{array}{l}\text { - } 30 \text { subjects or } 15 \text { subjects with very } \\
\text { tight control }\end{array}$ \\
\hline
\end{tabular}

Leaving from case and research goal that utters on previous part that is to uncover the influence of physical education through direct instruction towards skill to solve problem or students' adversity quotient, so method that used in ths research is Quasi Experimental Design with design that used is Non-equivalent Control-Group Design, as like looked in this following picture:

\begin{tabular}{|l|l|}
\hline $\mathrm{O}$ & $\mathrm{X}$ \\
\hline
\end{tabular}

Intrument that will be used for measuring adversity quotient is questionnaire in the form of likert scale that developed through indicators of adversity quotient that created by Stoltz. That scale is measure tool of psychologic that measures personality aspects that has characters like not judged true or false and the stimulation is ambiguous. Aspects in this adversity quotient include control (C), origin and ownership (O2) or reach $(\mathrm{R})$ or endurance (E) (Stoltz, 2010). If overall score on this scale is high so it shows the high adversity quotient, in contrarily if the total score that gained low so it shows the low adversity quotient too (Stoltz, 2010).

Table 3. Aspects of Adversity Quotient Measure (Stoltz, 2010).

\begin{tabular}{clc}
\hline No & \multicolumn{1}{c}{ Aspects } & Instrument \\
\hline 1 & Control $(\mathrm{C})$ & \\
\hline 2 & Origin and Ownership $(\mathrm{O} 2)$ & Questionnaire \\
\hline 3 & Reach $(\mathrm{R})$ & \\
\hline 4 & Endurance $(\mathrm{E})$ & \\
\hline
\end{tabular}

In this case, to facilitate process of validity analysis and statement reliability, researcher uses program of Statiscal Product and Service Solution (SPSS) realise 20, here are step arrangements of the testing:

1. To select questionnaire from the possibility of test item that not filled.

2. To give score on each of respondence answer alternative with scale that has made.

3. To conduct input data on program of Microsoft Excell.

4. To do test with Statiscal Product and Service Solution (SPSS) realise 20 with correlation technique in every test item.

Based on result of correlation test and analysis with program Statiscal Product and Service Solution (SPSS) realise 20, it is gained 44 statemnet items that stated valid and 16 statement items not valid. Here are criteria in determining valid test item:

1. If score of Corrected Item-Total Correlation> $(\mathrm{dk} \mathrm{n-2)}$ is 33 means 0,349 so item is stated valid.

2. If score Corrected Item-Total Correlation $<0,349(\mathrm{dk} n-2=32)$ so test item is stated not valid. 
The result of testing completely and detail for validity test of adversity quotient instrument can be seen on part of result of research. After conducting validity test, furthermore will be done reliability test towards statement item. The testing is done by referring on accounting of Cronbach's Alpha. Criterion in testing instrument realibility is if score of Cronbach's Alpha is bigger than 0,6 so the instrument is stated reliable. If score of Cronbach's Alpha more approaches number 1 so realibility of instrument has very high level. Based on the analysis result, it is achieved score of Cronbach's Alpha 0,941 means the instrument is realible and proper to be used for research.

\section{RESULT AND DISCUSSION}

The data of research result is gained through pre-test and post-test from every group of research by using research instrument that has tested validity and realibility. Here is the test result of the instrument of validity and realibility;

Table 4. Test Result of Instrument Validity of Adversity Quotient

\begin{tabular}{cl}
\hline Valid Statements & \multicolumn{1}{c}{ Not Valid Statements } \\
\hline $\begin{array}{c}\text { There are 44 valid statements } \\
(>0.349) \text { those are 1A, 2A, 2B, 3A, 3B, 4A, }\end{array}$ & valid \\
4B, 5A, 6A, 6B, 7A, 7B, 8A, 8B, 9A, 10B, & $(<0.349)$ those are 1B, 5B, 9B, 10A, 13A, \\
11A, 11B, 12A, 12B, 13B, 14A, 14B, 15B, & 15A, 16A, 16B, 19A, 19B, 20A, 20B, 24B, \\
17A, 17B, 18A, 18B, 21A, 21B, 22A, 22B, & 25B, 27B, 30B. \\
23A, 23B, 24A, 25A, 26A, 26B, 27A, 28A, & \\
28B, 29A, 29B, 30A. & \\
\hline
\end{tabular}

Table 5. Test Result of Instrument Realibility of Adversity Quotient (Cronbach's Alpha) Cronbach's Alpha $\quad$ Cronbach's Alpha Based on $\quad$ N of Items Standardized Items

,941 941160

The next step, the data of research result is processed and analyzed by using software program of Statiscal Product and Service Solution (SPSS) realise 20.

\section{Description of data Pre-Test Adversity Quotient}

Data of pre-test adversity quotient result in learning of physical education in group sample is gained before given treatment of direst instruction. Here are data of pre-test adversity quotient:

Table 6. Description of Result Data of Pre-Test Adversity Quotient

\begin{tabular}{ccc}
\hline & & Direct \\
\hline \multirow{2}{*}{$\mathbf{N}$} & Valid & 33 \\
\cline { 2 - 3 } & Missing & 0 \\
\hline Mean & 134,36 \\
\hline Median & 133,00 \\
\hline Std. Deviation & 13,917 \\
\hline Variance & 193,676 \\
\hline Range & 55 \\
\hline Minimum & 111 \\
\hline Maximum & 166
\end{tabular}


Rola Angga Lardika and Singha Tulyakul (2020)

The Effect of Direct Instruction Model in Physical Education Towards Students' Adversity Quotient (AQ)

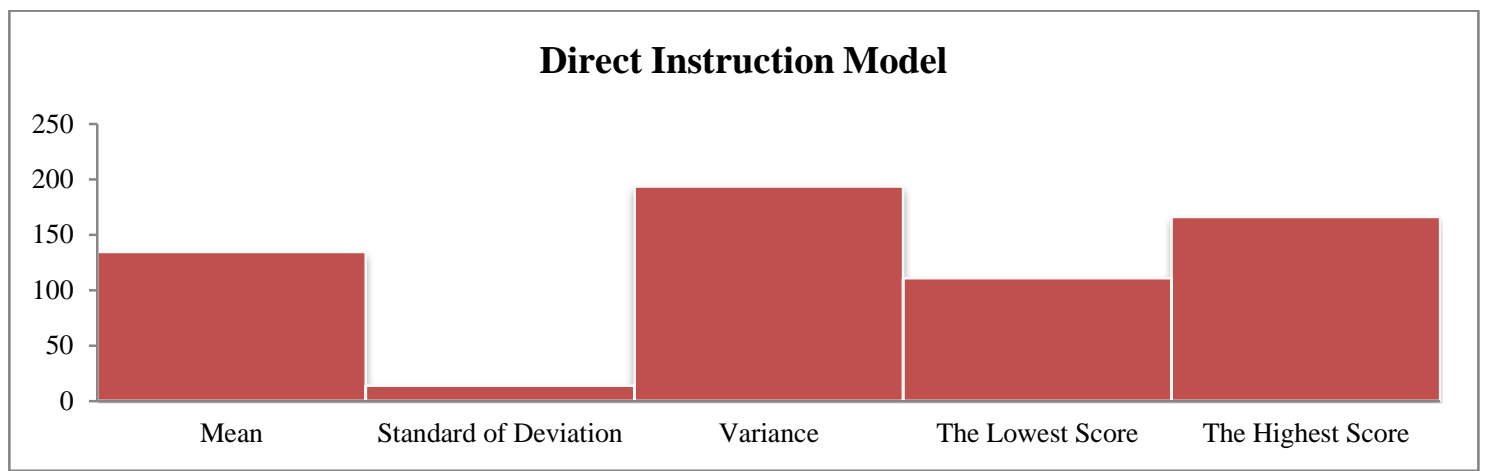

Picture 2. Description of Result Data of Pre-Test Adversity Quotient

Based on the result of processing of data that enclosed on table 6, it gains the result of proessing of data that on group of direct instruction learning model gets average of adversity quotient is 134,36 with standard of deviation 13,917 and variance 193,676. The lowest score in group of direct instruction model is 111 and the highest score is 166. Data above is the result of students' pre-test adversity quotient before given treatment on group of direct instruction model.

\section{Description of Data of Post-Test Adversity Quotient}

Data of post-testadversity quotient result in learning of physical education for every sample group is gained after given treatment direct instruction model. Each of group is given 8 times of meeting. Here are data of post-test adversity quotient:

Table 7. Description of Result Data of Adversity Quotient Post-Test

\begin{tabular}{ccc}
\hline & & Direct \\
\hline \multirow{2}{*}{$\mathbf{N}$} & Valid & 33 \\
\cline { 2 - 3 } & Missing & 0 \\
\hline Mean & 140,42 \\
\hline Median & 139,00 \\
\hline Std. Deviation & 12,405 \\
\hline Variance & 153,877 \\
\hline Range & 60 \\
\hline Minimum & 113 \\
\hline Maximum & 173 \\
\hline
\end{tabular}

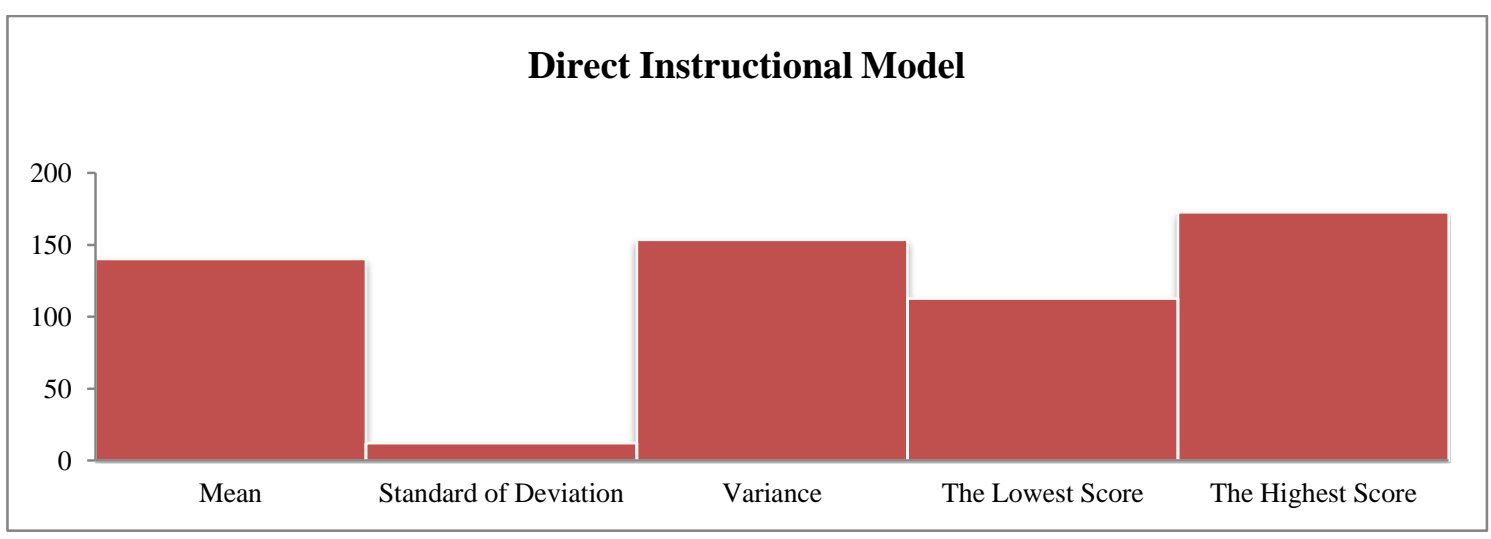

Picture 3. Description of Result Data of Adversity Quotient Post Test 
Based on the result of processing of data that enclosed on table 7, it is gained result that on group of direct instruction model gains average of adversity quotient is 140,42 with standard of deviation 12,405 an varian 153,877. The lowest score in group of direct instruction is 113 and the highest score is 173 .

\section{Description of Data Gain-Score Adversity Quotient}

Achievement of gain-score from result of pre-test and post test, from both of sample groups that is group of direct instruction model, the data can be seen on table 8 below:

Table 8. Data Description of Gain-Score Adversity Quotient

\begin{tabular}{ccc}
\hline & & Direct \\
\hline \multirow{2}{*}{$\mathbf{N}$} & Valid & 33 \\
\cline { 2 - 3 } & Missing & 0 \\
\hline Mean &, 08347 \\
\hline Median &, 08163 \\
\hline Std. Deviation &, 126090 \\
\hline Variance &, 016 \\
\hline Range &, 779 \\
\hline Minimum &,- 441 \\
\hline Maximum &, 338 \\
\hline
\end{tabular}

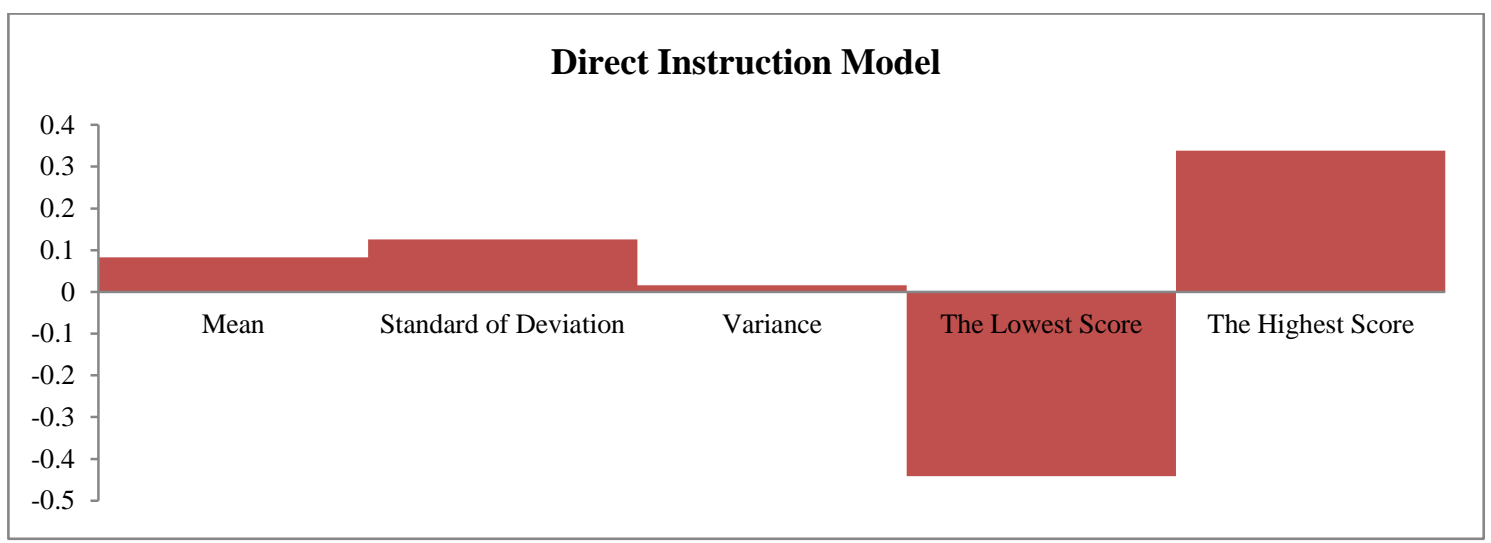

Picture 4. Data Description of Gain-Score Adversity Quotient

On table 8 can be elaborated gain-score between result of pre test and post test for group of direct instruction model that gained average 0,083 with standard of deviation 0,126 and variance 0,016 . The lowest score is $-0,441$ and the highest score is 0,338 .

\section{The Test Result of Adversity Quotient Normality}

Here author will elaborate the test result of data normality of pre-testadversity quotient result by using program of Statiscal Product and Service Solution (SPSS) realise 20 that can be seen on table 9 .

Table 9. Test Result of Data Normality of Pre-Test Adversity Quotient

\begin{tabular}{ccccccc}
\hline \multicolumn{3}{c}{ Kolmogorov-Smirnov $^{\text {a }}$} & \multicolumn{3}{c}{ Shapiro-Wilk } \\
\hline \multicolumn{2}{c}{ Statistic } & df & Sig. & Statistic & df & Sig. \\
\hline Direct & 0,09 & 31 &, $200^{*}$ & 0,966 & 31 & $\mathbf{0 , 4 1 1}$ \\
\hline
\end{tabular}


On table 9 encloses that data of normality result data for group of direct instruction model is gained the statistic score 0,966 with $\mathrm{dk} 31$ and probability score (sig.) 0,411 . The testing is based on comparing score probability (sig.) with $\alpha=0,05$. If score of probability (sig.) is bigger than $\alpha=0,05$ so the data is on normal distribution level. Whereas if score of probability (sig.) is smaller than $\alpha=0,05$ so the data is on innormal distribution level.

\section{The Test Result of Data Normality of Post-Test Adversity Quotient}

The test result of data normality of post-test adversity quotient for direct instruction model based on test of Kolmogorov-Smirnov can be seen on table 10.

Table 10. Test Result of Data Normality of Post-Test Adversity Quotient

\begin{tabular}{lcccccc}
\hline \multirow{3}{*}{ Direct } & \multicolumn{3}{c}{ Kolmogorov-Smirnov $^{\mathrm{a}}$} & \multicolumn{4}{c}{ Shapiro-Wilk } \\
\cline { 2 - 7 } & Statistic & df & Sig. & Statistic & df & Sig. \\
\cline { 2 - 8 } & $\mathbf{1 1 7}$ & $\mathbf{3 1}$ & ,200 $^{*}$ & $\mathbf{9 8 1}$ & $\mathbf{3 1}$ & $\mathbf{8 3 0}$ \\
\hline
\end{tabular}

The test result of data normality of post-test adversity quotient gains statistic score for sample group of direct instruction model is gained statistic score 0,981 with df 31 and score of probability (sig.) 0,830. Score of probability (sig.) 0,830 means that data of post-test adversity quotient for direct instruction model is on normal distribution level.

\section{The Test Result of Homogeneity}

After data is stated normal, the next step is testing data homogeneity. The test of homogeneity is done for getting to know if the data is from homogeneous population or not. Beside that the homogeneity test is done for determining statistic test that will be used in testing hypothesis; is it parametic statistic or non parametic. Because requirement for testing parametric statistic is the data should be normal and homogeneous.

\section{The Test Result of Homogeneity of Pre-Test Adversity Quotient Data}

For conducting homogeneity testing, researcher also uses SPSS by referring on probability score probabilitas (sig.), in this case, statistic test that used is lavene statistic. The test result of pre-test adversity quotient homogenitic can be seen on table 11 .

Table 11. Test Result of Data Homogeneity of Pre-Test Adversity Quotient

\begin{tabular}{cccc}
\hline Levene Statistic & df1 & df2 & Sig. \\
\hline, 654 & 1 & 32 &, 422 \\
\hline
\end{tabular}

The result from homogeneity testing for data of pre-test adversity quotient as like described on table 11 above, based on test of lavene statistic, it is gained average score 0,654 with df2 32 and probability score (sig.) 0,422. Furthermore, the testing result is based on on comparison between probability score (sig.) with $\alpha=0,05$. If score of probability (sig.) is bigger than $\alpha=0,05$ so research data is homogeneous, whereas if probability score (sig.) is smaller than $\alpha=0,05$ so the research data is not homogeneous. Based on average of probability score (sig.) 0,422 so it can be stated that result data of pre-test adversity quotient for group direct instruction model becomes from untuk population that has the same variation, means the research data is homogeneous. 


\section{The Test Result of Homogeneity of Post-Test Adversity Quotient Data}

The testing of homogeneity on group of post-test, researcher also uses SPSS by referring on score of probability (sig.), in this case, the statistic test that used is lavene statistic. The test result of homogeneity of pre-test adversity quotient can be seen on table 12 .

Table 12. Test Result of Data Homogeneity of Post-Test Adversity Quotient

\begin{tabular}{cccc}
\hline Levene Statistic & df1 & df2 & Sig. \\
\hline, 690 & 1 & 32 &, 409 \\
\hline
\end{tabular}

The result from homogeneity testing for data of post-test adversity quotient as like described on table tabel 4.7 above, based on test of lavene statistic, it is gained score average 0,690 with df 232 and probability score (sig.) 0,409. Based on average of probability score (sig.) 0,409 so it can be stated that result data of pre-test adversity quotient for group of direct instruction model comes from population that the same variation, means the research data is homogeneous.

\section{The Test of Hypothesis}

After normality and homogeneity test, the next step is testing research hypothesis. T-test is done by aiming to know if there is difference evidently from adversity quotient before treatment and after treatment on direct instruction model. Although there is criterion of testing, that is number $\mathrm{p}>0,05$ so hypothesis $\mathrm{H}_{0}$ is accepted $\mathrm{H}_{1}$ is rejected. For testing level of significance so the hypothesis testing is based on on comparison between probability score (sig.) that gained with $\alpha=0,05$. If probability score (sig.) $>\alpha$ $=0,05$ so the difference between result of pre-test and result of post-test is not significant. Whereas if probability score (sig.) $<\alpha=0,05$ so the difference between result of pre-test and result of post-test is significant. The result of accounting with Ttest of adversity quotient for control group with direct instruction model can be seen on table 13.

Table 13. Result of T-test of Adversity Quotient in Group of Direct Instruction Model

\begin{tabular}{|c|c|c|c|c|c|c|c|c|c|}
\hline & & \multicolumn{5}{|c|}{ Paired Differences } & \multirow{3}{*}{$\mathbf{t}$} & \multirow{3}{*}{ df } & \multirow{3}{*}{$\begin{array}{l}\text { Sig. } \\
(2- \\
\text { tail } \\
\text { ed) }\end{array}$} \\
\hline & & \multirow[t]{2}{*}{ Mean } & \multirow{2}{*}{$\begin{array}{l}\text { Std. } \\
\text { Devi } \\
\text { ation }\end{array}$} & \multirow{2}{*}{$\begin{array}{l}\text { Std. } \\
\text { Error } \\
\text { Mean }\end{array}$} & \multicolumn{2}{|c|}{$\begin{array}{c}\text { 95\% Confidence } \\
\text { Interval of the } \\
\text { Difference }\end{array}$} & & & \\
\hline & & & & & Lower & Upper & & & \\
\hline $\begin{array}{c}\text { Pair } \\
1\end{array}$ & $\begin{array}{l}\text { Pretest - } \\
\text { Posttest }\end{array}$ & $-6,061$ & 6,892 & 1,200 & $-8,504$ & $-3,617$ & $-3,052$ & 32 &, 000 \\
\hline
\end{tabular}

On table 13 is known that the difference between result of pre-test and post-test of adversity quotient on group of direct instruction model has score (sig.) is 0,000 with deviation 6,892. Score (sig.) is 0,000 and score of $\alpha=0,05$. So score (sig.) is smaller than $\alpha=0,05$, means $\mathrm{H}_{1}$ is accepted and $\mathrm{H}_{0}$ is rejected. Thus, there is the significant difference between result of pre-test and post-test on control group by using direct instructional model. Thus it can be concluded that there is the significant influence from direct instruction model towards students' adversity quotient level.

Direct instruction model is learning model centers on teacher, teacher is demanded be creative in preparing and practicing the lesson material. Direct instruction less gives opportunity to students in developing self potency so students will get understand based 
on understanding of teacher and students can not pass understanding and knowledge of the teacher. This case is caused by the limitation access of students for giving analysis and conclusion of their thinking. As like what explained by Edgen and Kauchak (2012) direct instruction is one model that uses teachers' simulation and teaching compounded with students' exercise and feed back for helping them to achieve real knowledge and skill that needed to futher learning.

Then Amri and Ahmadi (2010) state that direct instruction is one learning model that designed specially for developing students' learning about procedural knowledge and declarative knowledge that arranged well and can be learnt step by step. The learning of physical education through direct instruction model also gives movement assignments that students should accomplish so students are demanded to accomplish it. Indirectly, activity of direct instruction also demands accomplishment of movement problem or adversity quotient. It can be concluded that every activity of human in accomplishing problem with an exact concept can influence quotient level in solving problem on individual. From the search that gained in field that direct instruction model gives influence towards level of students' adversity quotient. This case can be seen from gain-score that gained after giving treatment. Based on the search and the note in field, when students are given a movement exercise, students with each of ability effort to accomplish it. In this research, the researcher takes conclusion that there are steps in direct instruction that also need process in solving problems although in the accomplishment is dominated by psychomotoric factor. Rosenshine in Metzler(2000) identified 6 steps in direct instruction learning, those are: 1) Pay attention learning instruments. Direct instruction should begin by evaluating the previous learning. In this step teacher prepares all instruments and materials in learning process by staying to pay attention the learning process that has been ever given. 2) Ability to deliver material. Assignment is given to students with language and body description clearly and not confusing. This will give description to students towards ideas that they look. Obviously, the description is appropriate with students' ability level. 3) Students' preexercise. Task of delivering is led directly into exercise structure, included making students in part of pre-learning. The exercise should give number of high response with teacher uses controlling in feed back. 4) Feed back and correction. Teacher should give feed back and statemnet correction or together with students do sequence of exercise each other. Teacher may choose or repeat some keys in sign performance and repetition in learning. 5) Independence exercise. One of teacher should be self-confident that students has basic and controlling, and the teacher should be able to plan students towards more independent exercise. Teacher should design learning activity and lead delivering towards students, but students make decision theirselves about the goals. In enhancing of students' response number. 6) Periode of evaluation. Teacher should evaluate learning as often as possible. For solving internal and external difficulty for school, so it is be obligation for school administrator to own relevant quality that required to be success (Okorji \& Epetuku, 2019). The activity of this evaluation assists teacher in getting to know the development of students and what part that will be established in the next learning. Based on several searches and analysis above, it can be concluded that direct instruction model will influence adversity quotient level although every activity of learning is not direct relating with cognitive theory that used as builder of adversity quotient level be focus from this research. 


\section{CONCLUSION}

Based on the result of processing and analyzing of data, it is gained answer towards questions of research that proposed. Here is conclusion that achieved: direct instruction model in physical education in school giving the significant influence towards students' adversity quotient (AQ) level.

\section{REFERENCES}

Abduljabar, B. (2010). Landasan Ilmiah Pendidikan Intelektual dalam Pendidikan Jasmani. Bandung: Rizki Press.

Abduljabar, B. (2011). Modul Pedagogi Olahraga. Bandung: UPI Prodi PJKR.

Amri, S. \& Ahmadi, I. K. (2010). Proses Pembelajaran Kreatif dan Inovatif Dalam Kelas. Jakarta: Prestasi Pustaka Publisher.

Bingquan, L., Weisheng, C., Xudong, Z., \& Wenxiu, Z. (2019). The Compilation of The Adversity Quotient Scale for College Students. Psychology and Behavioral Sciences, 8(1), 9-14. https://doi.org/10.11648/j.pbs.20190801.12

Edgen, P. \& Kauchak, D. (2012). Strategi dan Model Pembelajaran. Jakarta: PT Indeks.

Gall, M.D., Gall, J.P., \& Borg, W. R. (2013). Educational Research. USA: Pearson Education, Inc.

Khairani, A. Z., \& Abdullah, S. M. S. (2018). Relationship between adversity quotient and academic well-being among Malaysian undergraduates. Asian Journal of Scientific Research, 11(1), 51-55. https://doi.org/10.3923/ajsr.2018.51.55

Maksum, A. (2012). Metodologi Penelitian dalam Olahraga. Surabaya: Unesa University Press.

Metzler. M. W. (2000). Instructional Models For Physical Education. London: Allyn \& Bacon.

Mwivanda, M., \& Kingi, P. M. (2019). Teachers' Adversity Quotient Dimension of Control and Students Academic Performance in Secondary Schools in Kenya. Journal of Education and Training, 6(1). https://doi.org/10.5296/jet.v6i1.14373

Napis, N. (2018). Analysis of Physics Problem Solving in The Perspective of Self Efficacy and Adversity Quotient. Formatif: Jurnal Ilmiah Pendidikan MIPA, 8(1), 31-42. https://doi.org/10.30998/formatif.v8i1.2298

Okorji, P. N., \& Epetuku, F. (2019). Relationship Between Principals Adversity Quotient and Leadership Styles in Secondary Schools in Delta State, Nigeria. International Journal of Scientific and Research Publications (IJSRP), 9(7), 938945. p91123. https://doi.org/10.29322/ijsrp.9.07.2019.p91123 

(AQ)

Rusman. (2012). Model-Model Pembelajaran. Jakarta: PT. Raja Grafindo Persada.

Stoltz, P. G. (2010). Adversity Quotient Mengubah Hambatan Menjadi Peluang. Jakarta: PT Gramedia.

Yakoh, M., Chongrukasa, D., \& Prinyapol, P. (2015). Parenting Styles and Adversity Quotient of Youth at Pattani Foster Home. Procedia - Social and Behavioral Sciences, 205. https://doi.org/10.1016/j.sbspro.2015.09.078 